\title{
The Effectiveness of Meaningful Approach in Enhancing Students' Speaking Skill at German Language Study Program, Faculty of Languages and Literature, State University of Makassar
}

\author{
Misnawaty Usman \\ Universitas Negeri Makassar, Jln. Bonto Langkasa, Kampus Gunung Sari, Makassar, South Sulawesi, Indonesia \\ Alimuddin Mahmud \\ Universitas Negeri Makassar, Jln. Bonto Langkasa, Kampus Gunung Sari, Makassar, South Sulawesi, Indonesia \\ Muhammad Asfah Rahman \\ Universitas Negeri Makassar, Jln. Bonto Langkasa, Kampus Gunung Sari, Makassar, South Sulawesi, Indonesia \\ Darman Manda \\ Universitas Negeri Makassar, Jln. Bonto Langkasa, Kampus Gunung Sari, Makassar, South Sulawesi, Indonesia
}

\begin{abstract}
This study aims at determining the effectiveness of meaningfulness approach in enhancing students' speaking skill at German Language Study Program, Faculty of Languages and Literature, State University of Makassar. This study used a Pre - Experimental Design, and applied one group pre-test - post-test design. The population was the fifth semester student years 2011-2012 at the German language education study program with the total sample was 64 students by using total sampling method. Inferential statistics analysis in form of $t$-test was used to test research hypothesis. The result of this study showed that $t=4,09$ is higher than $t$ - table ( $t$ table $=1,999$ ) at the significance level 0.05 or $4,09 \geq 1,999$. The result showed that the meaningfulness approach was effective in enhancing students' speaking skill at German Language Study Program, Faculty of Languages and Literature, State University of Makassar.
\end{abstract}

Index Terms - effectiveness, meaningfulness approach, speaking skill, German language

\section{INTRODUCTION}

In the context of language teaching there are four skills which are required for the students to be mastered. These four language skills are aimed to make students skilled in reading, listening, speaking, and writing in a foreign language/German and one of the expectation is the positive application of the German language, both written and oral in order to be used in communication .

To actualize it, the teaching on German language are expected to have capability of providing learning facilities and provide adequate learning conditions which is allowing the students to be more enthusiastic to learn German language. The atmosphere and facilities in the classroom are influenced by various factors, among others, lecturers, students, learning objectives, lesson materials, teaching methods, and also teaching media. These factors constitute a chain that cannot be separated and have a reciprocal relationship.

Meaningfulness approach as a part of the communicative approach was stemmed from a change in the tradition of language teaching in the UK in the 1960s. In 1971 a group of experts began to explore the possibility of the development on language lessons based on unit credit system, a system that elaborate learning tasks into portions or related units and appropriate with the learner and systematically associated with all portions or other units. (Van EK \& Alexander: 1980).

This group employed studies on the needs of language learners in Europe, and in particular employed a preliminary document which had provided by the British linguist, David A. Wilkins in 1972 (Abdullah, 2000:80). This linguist proposed a functional or communicative definition of language that can be used as a basis for the development of communicative syllabuses for language teaching, as practiced by Keith Johnson (2001) and Janice Yalden (2003).

The Concept of Wilkins is an analysis of the communicative meanings which is required by language learners to be understood and expressed. In addition to examine the core material language through the concept of grammar and traditional vocabulary, Wilkins sought to demonstrate the difference of the meaning systems behind the use of communicative language. He proposes two types of meaning category, namely national categories (concepts such as 
time, order, quality, location, frequency) and communicative function categories (request, rejection, offer, and complaint).

The works of Wilkins, Candlin, Christopher Brumfit, Keith Johnson and the other applied linguistics expert on the basics theoretical of communicative and functional approach to the language teaching, the rapid and repetitive application of these ideas by the authors of the textbook; and also rapid acceptance toward the recent principles by specialist experts of English language teaching, curriculum development centres and even the government; to participate on the national and international admission of communicative approach or communicative language teaching, or in other words the notional functional approach or functional approach (Tarigan, 2008, p. 51-52).

Some studies, such as conducted by Sabo (2004) concluded that the learning achievement of German language on public and private high school students in Makassar was in the low level category (54.65\%). The linguists and foreign language teaching experts in Indonesia are in quest of the failure causes of the foreign language teaching. Burhan (2011:11) stated that the failure was derived from teachers and teaching methodology. Another assumption to say that it was caused by foreign language teaching is more emphasize on the knowledge theory of foreign language, but less in practicing.

From the phenomenon in the field, the mastery of German language, especially speaking skill (sprechfertigkeit) in the real situation is still far from the expectations. As Hawis (2005) found that the students in general (72.45\%) still have difficulty in expressing their ideas by using the German language. The same thing also expressed by Usman (2008) who stated that the mastery of the German language speaking skill especially using the communicative method is more effective than the grammatical method. Supporting research also proposed by Usman (2007) who found that the learning of speaking skill (sprechfertigkeit) through a questioning model toward the students of The Department of Foreign/German language education showed a significant progress. The Students were more courage to use the German language in the form of a conversation such as daily activities (Tagesablauf).

Based on several studies that have been mentioned above and the phenomena in the field, particularly for the students of German language education at the Faculty of Language and Literature University of Makassar, it is necessary to conduct research on the effectiveness of the approach significance (communicative) in teaching speaking skills (sprechfertigkeit) in the study program on the basis of the steps or procedures meaningfulness approach.

Based on the background of study mentioned above, the formulation of the problem of this research was: "Does the application of meaningfulness approach effectives in improving the speaking skills (sprechfertigkeit) of the students of the German language education FBS - UNM?".

\section{METHODS}

\section{A. Variables and Research Design}

\section{Variables}

This study consisted of two variables, namely: the independent variables and the dependent variable. The Meaningfulness approach as the independent variable (X), while the speaking skill (sprehfertigkeit) as the dependent variable (Y).

\section{Research Design}

This study was a Pre-Experimental Design, in form of one group Pretest-Posttest Design (Sugiyono,2008:109), which aims to determine the effectiveness of the meaningfulness approach in improving the speaking skill (sprechfertigkeit) on German Language of the students of German Language education FBS UNM.

\section{B. Definition of Operational Variables}

\section{Meaningfulness Approach}

Meaningfulness approach as a part of the communicative approach in this research is an approach that emphasizes the ability to communicate and focuses on the meaningfulness of language and communicative functions. Thus, language teaching should be based on the meaning of language that is to use language in communicating.

Teaching and presentation of language forms are always connected with the intention of meaning and message which is appropriated with the actual context and situation. In particular, the meaningfulness approach is meant on how the teachers implement this approach in the German language teaching, especially teaching speaking skill (sprechfertigkeit) which includes; preparation and implementation, and the way teachers enclose an understanding of meaningfulness approach concept which includes; definition, characteristics, and procedures adopted in teaching German Language in German language Education study program of FBS UNM.

\section{Speaking Skill (Sprechfertigkeit)}

The Speaking skill (sprechfertigkeit) which is referred in this research was the ability of a person to tell, express, say and convey their thoughts, feelings, and ideas to others which include: (1) Understanding of the meaning, namely the ability to understand the contents, meaning and also understanding of each topic or the talking theme, (2) reaction , which is a person's ability to react quickly in responding the conversation, (3) speaking skill creatively by applying language and general knowledge in communication, (4) the mastery of the expression is the ability which associated with the ability to understand or use the vocabulary, syntax and the right expression, (5) Pronunciation with 
emphasizing on the speaker 's ability to pronounce sounds correctly, including speech and tempo (speed) of speaking, (6) Morphological/syntax, criteria is assessed in this aspect is the ability of using elements of morphology and syntax.

\section{Population and Sample}

The population in this study were the students of fifth semester of 2012 class of the German language education study program with total sample was 64 students, and the sample used in this study was the total sample.

\section{Data Collection Technique}

The technique of data collection in this study was splitting each sample into two parts. Some were placed into the control class and some were placed into experimental class which determined randomly. The sample on the experimental class was taught by meaningfulness approach, while the control class was taught by grammatical approach. After that, each sample was given a written test in the form of essay tests, both the control and the experimental class.

The written test was used to measure the student's speaking ability. The steps taken were:

1. Conducting a pre-test, the test was given before the teaching begins that is aimed to determine the level of student's mastery of the lesson material that will be taught .

2. The treatment was in the form of content delivery or teaching materials that had been designed previously which is carried out during four meetings.

3. Providing a Post-test, a test that was given at the end of the teaching. The purpose of this test is to determine the extent of student achievement (learning outcomes) after experiencing a learning activity (receiving a treatment).

\section{E. The Techniques of Data Analysis}

The test results of speaking skill were analyzed by using:

1. Inferential Statistic Analysis

Inferential Statistics analysis was used to test the hypothesis of the research by using t-test. However, before testing the hypothesis, it was previously conducted the homogeneity and normality test using $\mathrm{z}$-score table and chi squared, before the decisive test for normality and homogeneity the data, as well as hypothesis testing it was determined the mean (average), standard deviation and variant.

The formula respectively as follows:

* The formula (average):

* Standard deviation formula: $\quad \overline{\mathrm{X}}=\frac{\sum \mathrm{f}_{\mathrm{i}} \cdot \mathrm{x}_{\mathrm{i}}}{\sum \mathrm{f}_{\mathrm{i}}}{ }_{\text {(Sudjana, 2005, p. 67) }}$

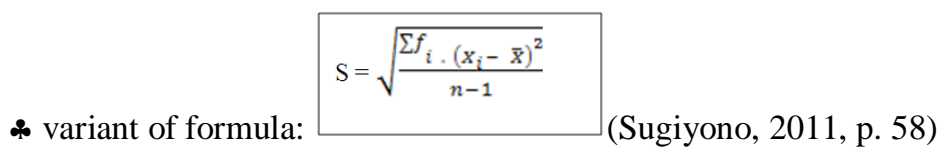

2. Normality test aims to determine whether the data on the sample used normal distribution or not. Before the posttest data was analyzed using t-test, at first it was tested the normality. To test the normality of the data it was used chisquare formula as follows:

$$
\begin{aligned}
& \chi^{2}=\sum_{i=0}^{n} \frac{\left(\mathrm{f}_{\mathrm{o}}-\mathrm{f}_{\mathrm{h}}\right)^{2}}{\mathrm{f}_{\mathrm{h}}} \\
& \text { Where: } \\
& \mathrm{X} 2=\text { Chi Square } \\
& \text { fo }=\text { Frequency observed } \\
& \text { fh }=\text { Frequency expected } \\
& \text { (Sugiyono, 2011, p. 107) }
\end{aligned}
$$

3. Test of Homogeneity

Homogeneity test was used to determine whether the sample is a homogeneous variant or not. Pre-test data is needed to determine whether the data obtained is homogeneous or not . To determine the homogeneity, it was conducting a homogeneity of variant testing using the $\mathrm{F}$ (Fischer) test with the formula as follows:

$$
\begin{aligned}
& \hline F_{\text {count }}=\frac{\text { Largest variant }}{\text { Smallest variant }} \\
& \hline \mathrm{F} \text { count }=\text { (largest variant) / (smallest variant) } \\
& \text { With the testing criteria, namely: } \\
& \text { Accept } \mathrm{H} 0 \text { if } \mathrm{F} \text { count }<\mathrm{F} \text { table; and } \\
& \text { Reject } \mathrm{H} 0 \text { if } \mathrm{F} \text { count }>\mathrm{F} \text { table } \\
& \text { (Supardi, 2013, p. 143) }
\end{aligned}
$$


4. T-test was conducted to test the hypothesis and then compared with the t-distribution table to determine whether Ho rejected or accepted and $\mathrm{H} 1$ accepted or rejected, the criteria of the formula as follows:

- Reject $\mathrm{H} 0$ if $\mathrm{t}$ count $\geq \mathrm{t}$ table and

- Accept H0 if tcount $\leq \mathrm{t}$ table

$\mathrm{t}$ - test formula:

$\mathrm{t}=\frac{\boldsymbol{x}_{A}-\boldsymbol{x}_{B}}{\sqrt{\left(\frac{1}{n_{A}}+\frac{1}{n_{B}}\right)}}$

Where:

$S_{\text {com }}=\sqrt{\frac{\left(n_{A}-1\right) s_{A}^{n}+\left(n_{B}-1\right) s_{B}^{n}}{n_{A}+n_{B}-2}}$

Specification :

$\bar{X}_{A}=$ the mean score of the experimental group

$\bar{X}_{A} \quad=$ the mean score of the control group

$S_{A}^{2}=$ variant of the experimental group

$S_{B}^{2}=$ variant of the control group

$\mathrm{n}_{\mathrm{A}}=$ number of samples of the experimental group

$\mathrm{n}_{\mathrm{B}} \quad=$ number of samples of the control group

$\mathrm{S}_{\mathrm{com}}=$ the combined of standard deviation

(Supardi, 2013, p. 329)

\section{FINDINGS AND DISCUSSIONS}

In this study, the learnings were done during four meetings. In the learning, both classes were taught by using different methods. In the experimental class the students were taught through meaningfulness approach to improve speaking skill of the students, while in the control class, the students were taught by grammatical approach. In the learning process, the students are always given speaking task. Pre-test results showed that the average value (mean) of the students' speaking ability are relatively equal, the highest value for the experimental class was 60 and the lowest value was 20, the highest value of the control class was 55 and the lowest value was 25 . The lowest test value for normality on the pre-test data of both classes indicated that the experimental and control class had their chi- squared count were smaller than the chi squared table,$\chi_{\text {count }}<\chi_{\text {table }}$. Pre-test of experimental class was $(3.29<11.070)$ and Pre-test of control class was $(1.59<11.070)$, so that the distribution of pre-test data was stated normal.

The results showed that through the application of the meaningfulness approach, the students are more active and courage to express their opinions orally in comparison with the learning through the grammatical approach. In addition, students' enthusiasm and motivation between the class whom taught the meaningfulness approach was very different than the class whom taught grammatical approach, the experimental class students more enthusiastic and interested in learning German language as compared with the control class, students in the experimental class were able to see and hear the correct pronunciation and intonation of the native speakers dialect of German language and can add new vocabulary for students.

Based on the post-test results, the application of the meaningfulness approach on the learning process had a positive impact on improving students'speaking skill. From 32 samples in the experimental class, there were two students were obtained 80 , four students were obtained 75 , five students were obtained 70 , three students were obtained 65 , seven students were obtained 60. Two students were obtained 55. Seven students were obtained 50. One student was obtained 45 and one student was obtained 35. The post-test data showed that the average value (mean) of the experimental class was 60.4 , from the lowest value was 35 and the highest value was 80 . The mean of the control class was 50.47, from the lowest value was 35 and the highest value was 70. Based on the post-test result, the value of both classes has increased, but the results of post-test experimental class is higher than the value of the control class.

In the post-test data of normality test for each class were not showing the same result, were the class chi squared count of the experimental was smaller than its chi squared table, $\chi_{\text {cownt }}<\chi_{\text {table }},(2.53<11.070)$ so that the distribution data is stated normal. While the chi squared count of the control class was higher than its chi squared table, $\chi_{\text {count }}<\chi_{\text {table }},(20.85<11.070)$ so that the data distribution is stated normal. The results of analysis above were followed by a t-test to find out the final results of this research, the test for each class has the same formula. The result of $t_{\text {count }}$ for the experimental class was 4.09 while its $t_{\text {table }} 1.999$, so $t_{\text {count }} \geq t_{\text {table }}$ (4.09 $\geq 1.999$ ).

As the result, accept H1 statement: Meaningfulness approach is effective in improving speaking skill (sprechfertigkeit) on German Language of the students of German language education FBS UNM, and reject H0 statement: Meaningfulness approach is not effective in improving the speaking skill on German Language of the students of the German language education FBS UNM. So it can be concluded that the meaningfulness approach is 
effective in improving the speaking skill (sprechfertigkeit) on German language of the students of German language education FBS-UNM.

Based on the research that had been conducted it showed that teaching with the application of meaningfulness approach is an alternative to solve the difficult problems of enhancing the speaking skill (sprechfertigkeit) on German language of the students. Meaningfulness Approach is helped the students in learning, because it can enhance knowledge, vocabulary, the term, the power of imagination, creativity, and critical thinking of students, they also can see and hear the correct pronunciation and intonation in speaking German language by its native speakers, and it also fosters the spirit and motivation of students to gain further knowledge. So, it can be said that the use of learning methods which appropriate with the character of the students can enhance the interest and the learning outcomes of the students toward German language, particularly speaking skill (sprechfertigkeit).

\section{CONCLUSION}

Based on the results of the data analysis described in the previous chapter, it can be concluded that the meaningfulness approach in German language teaching is effective in enhancing speaking skill on German language of the students of German language education FBS-UNM. It is evidenced by the results of the data analysis which found that the value of post-test after the t-test in each group where th=4.09 $>\mathrm{t} t=1.999$ at a significance level of 0.05 , which means that the application of meaningfulness approach on the German language teaching is effective and enhance the speaking skill of the students of German language education FBS-UNM.

\section{SUGGESTION}

In order that in the learning of German language, particularly speaking skill more attractive and the students learning outcomes enhance, it is suggested:

1. The educators should be more innovative in selecting and applying the approaches, methods, and techniques in the teaching of speaking to attract the student's interest in learning, designing a wide variety of learning to make the students motivated to learn German and avoid saturation of learning for the student.

2. The educators should be more creative in managing the various learning process in teaching so that the atmosphere in the teaching process does not tend to be rigid and monotonous.

3. For students, to be more utilize technology in obtaining information or material that will be taught/presented, so that the students can more practice independently or in groups.

4. To the relevant agencies, both government and private sectors, especially in the field of foreign language teaching should pay particular attention to infrastructure of German language teaching, because German language is a new foreign language in language learning and teaching resources are still lacking.

\section{REFERENCES}

[1] Arsyad, Azhar. (2005). Media Pengajaran. Jakarta: PT Raya Grafindo Persada.

[2] Burhan, J. (2004). Problema Bahasa dan Pengajaran Bahasa. Bandung: Ganaco

[3] Brunfit, C. (2002). Language and Literature Teaching. Oxford: Oxfor University Press.

[4] Brumfit, C. \& Keith J. (Peny.). The Communication Approach to Language Teaching. Oxford: Oxford University Press.

[5] Cangara, Hafied. (2011). Pengantar Ilmu Komunikasi. Jakarta : PT Raja Grafindo Persada.

[6] Chaer, Abdul. (2004). Linguistik Umum. Jakarta: Rineka Cipta.

[7] Chaer, Abdul. (2000). Tata Bahasa Praktis Bahasa Indonesia. Jakarta : PT Rineka Cipta.

[8] Depdiknas. (2003). Kurikulum 2004 Standar Kompetensi Mata Pelajaran Bahasa Jerman. Jakarta. Depdiknas

[9] Dryden, Gordon \& Jeannet Vos. (2001). The Learning Revolution I; Keajaiban Pikiran. Bandung, Kaifa.

[10] Dryden, Gordon \& Jeannet Vos. (2004). The Learning Revolution Isekolah Masa Depan. Bandung, Kaifa.

[11] Hymes, D. (2002). On Communication Competence. England: Penguin Education.

[12] Johnson, K. \& Keith.M. (2001). Communicative in the Classroom Application and Method for a Communicative Approach. Oxford: Oxford University Press.

[13] Nunan, D. (2000). DesigningTaks for Communicative Classroom. Cambridge: Cambridge University Press.

[14] Richards, J.C. \& Theodore S.R. (2004). Approach and Method in Language Teaching. New York:Cambridge University Press.

[15] Saleh, Nurming. (2002). Efektivitas Komunikasi Instruksional dalam Pengajaran Bahasa Jerman (Studi Perbandingan antara Efektivitas Metode Pengajaran yang Menggunakan Alat Bantu Audio Visual dengan Metode yang Menggunakan Bahan Ajar Tertulis terhadap Keterampilan Berbicara Mahasiswa Program Studi Bahasa Jerman FBSUNM) Tesis. UNPAD Bandung

[16] Saud, Syukur dan Misnawaty Usman. (2004). Komunikasi Instruksional dalam Pengajaran Bahasa Jerman Mahasiswa Jurusan Pendidikan Bahasa Asing/Jerman FBS UNM. Laporan Penelitian . Dikti.

[17] Slameto. (2003). Belajar dan Faktor-Faktor yang Mempengaruhinya. Jakarta : PT Rineka Cipta.

[18] Sudirman. (2006). Interaksi dan Motivasi Belajar Mengajar. Jakarta : PT Grafindo Persada.

[19] Sudjana. (2005). Metoda Statistika. Bandung: Tarsito

[20] Sudjana, Nana. (2007). Dasar-Dasar Proses Belajar Mengajar. Bandung. Sinar Baru.

[21] Sudjana, Nana \& Ahmad Rivai. (200)1. Teknologi Pengajaran. Bandung. Sinar Baru.

[22] Sugiyono. (2008). Metode Penelitian Pendidikan, Pendekatan Kuantitatif, Kualitatif, dan R\&D: Bandung: Alfabeta.

[23] Sumardi, M. (2005). Pengajaran Bahasa Asing. Jakarta: Bulan Bintang

[24] Tarigan, H.G. (2008). Pengajaran Bahasa Komunikatif. Bandung: Angkasa 
[25] Usman, Misnawaty. (2002) Perbandingan Prestasi Belajar Mahasiswa Program Studi Bahasa Jerman FBS UNM yang diajar dengan menggunakan Metode Komunikatif dengan Metode Tradisional dalam Konteks Komunikasi Instruksional. Tesis. UNPAD Bandung.

[26] Usman, Misnawaty. (2007). Pembelajaran Keterampilan Berbicara (Sprechfertigkeit) Melalui Model Questioning Mahasiswa Jurusan Pendidikan Bahasa Asing/Jerman semester V FBS-UNM.

[27] Widjaja. (2006). Ilmu Komunikasi. Jakarta : Rineka Cipta.

[28] Yalden, J. (2003). The communication Syllabus. New Jersey: Prentice Hall International.

Misnawaty Usman - The lecturer of educational study program German Language, Faculty of Languages and Literature. Misnawaty Usman was born on December 24, 1962 in Parepare. She is currently pursuing his doctoral program in the field of science education at the State University of Makassar. Bachelor's degree in Foreign Language Education/Germany acquired in Ujung Pandang. Teachers' Training College and a Master of Communication Science of the University of Padjadjaran. She began teaching courses in Entrepreneurship study programs since 2013 and managed to arouse interest in students to start entrepreneurship and explore the potential of each to produce unique works from materials that have a secondhand sale value. Misnawaty attended german language course in Mannheim-Wes Germany on June-August 1988. As participant Indonesian Dotate of America, October 31,2012 through January 16, 2013.

Alimuddin Mahmud, was born in Majene on October 15, 1954. Degree (S1) in the field of Guidance and Counseling at IKIP Ujung Pandang in 1980, graduated from S2 in the field of guidance and counseling in Malang in 1995, and earned doctorate in 2005 at the State University of Malang. Alimuddin Mahmud is a professor in the field of guidance and counseling and as a lecturer in the Department of Guidance and Counseling Faculty of Education, University of Makassar. In addition to teaching at the S1 level, he is also active in teaching and guiding students on level S2 \& S3 graduate program Makassar State University. As a coach Course in Thesis Writing and Research Skills at The University Of Canberra organized by the University of Canberra English Language Institute in 2008. His recent work is a book entitled Marriage and Family Counseling, published in 2016 by publishing of UNM, ISBN 97-602-6883-24-7.

Muhammad Asfah Rahman received his Ph.D in instruction \& Learning/Instructional Design and Technology at the University of Pittsburg, PA, USA. He is currently an associate professor in the Faculty of Literature and Language, State University of Makassar, Makassar, Indonesia. His research interests include early reading program for learners of English as a foreign language. He is also currently a member of Indonesian Linguistic Society (MLI), Indonesian Education Scholars Association (ISPI) and TEFLIN (Teaching English as a Foreign Languange in Indonesia). He has been teaching English as a foreign language at FBS UNM for more than 30 years, with strong background in instructional design and technology and a lot of experience in elementary and second ary school teacher training, teacher professional development, and teaching English to young learners.

Darman Manda, was born on January 3, 1965. Graduated Polewali elementary and junior high schools in Barru. SMA Negeri 5 Makassar Graduated 1984. Graduate Teachers' Training College history FPIPS Ujung Pandang 1989. S2 Padjadjaran University in Bandung, 1996. Short Course, La Trobe University, Bendigo VictoriaA Australia, 1997. S3 Anthropology, University of Hasanuddin, 2007. Darman Manda is a lecturer in the Faculty of Social Sciences Makassar State University and currently serves as Chairman of the Anthropology Studies Program in the Graduate Program UNM. 